\title{
CLAY MINERALS IN THE ROCK SALT OF MIOCENE EVAPORITES OF THE CARPATHIAN REGION, UKRAINE
}

la.V. Iaremchuk, S.P. Hryniv

\section{МІНЕРАЛЬНИЙ СКЛАД ГЛИН КАМ'ЯНОЇ СОЛІ МІОЦЕНОВИХ ЕВАПОРИТІВ КАРПАТСЬКОГО РЕГІОНУ УКРАЇНИ}

\author{
Я.В. Яремчук, С.П. Гринів
}

Clay mineral association in water insoluble residue of 33 rock salt samples from Miocene evaporites of the Carpathian Foredeep were investigated by means of X-ray diffraction (XRD).

The clay minerals of halite facies of the Carpathian Region of Ukraine in both Eger-Eggenburgian (Vorotyshcha suite) and Badenian (Tyras and Tereblya suites) rock salt deposits contain illite, chlorite and mixed-layer illite/smectite, while the smectite, mixed-layer chlorite/smectite and corrensite is revealed only in Badenian rock salt and is caused by volcanic activity in Badenian.

Key words: rock salt, clay minerals, Carpathian Region.

Узагальнення наших (33 проби) і літературних даних для Карпатського регіону України свідчить, що глинисті мінерали евапоритів галітової стадії галогенезу крім гідрослюди та хлориту, містять змішаношаруваті утворення - гідрослюдамонтморилоніт у кам'яній солі воротищенської світи (егер-еггенбург) і хлорит-монтморилоніт, а також монтморилоніт, коренсит та домішку гідрослюди-монтморилоніту у відкладах тираської та тереблинської світ (баден). Асоціація глинистих мінералів тираської та тереблинської світ пов'язана з баденським вулканізмом.

Ключові слова: кам'яна сіль, глинисті мінерали, Карпатський регіон.

\section{ВСТУП}

Як відомо, в евапоритовому процесі склад глинистих мінералів змінюється залежно від стадії згущення розсолів евапоритового басейну [22]. Ці стадії визначаються за складом солей, що кристалізуються при послідовному згущенні розсолів, - гіпсова, галітова та стадія садки калійних солей. Для Передкарпатського прогину склад глин калійних солей достатньо вивчений $[6,1,5,10,19]$, так само вивчені і глини кам'яної солі Закарпатського прогину [2, 15, 9].

Мета даної роботи - встановити мінеральний склад глин кам'яної солі Передкарпатського прогину та з врахуванням літературних даних представити узагальнюючу картину мінерального складу глин галітової стадії евапоритів Карпатського регіону України.

\section{ГЕОЛОГІЧНІ ОСОБЛИВОСТІ РАЙОНУ ДОСЛІДЖЕНЬ}

Міоценові евапоритові відклади у Карпатському регіоні України поширені у Передкарпатському та Закарпатському прогинах. У Передкарпатському прогині вони залягають у Бориславсько-Покутській (воротищенська світа, егер-еггенбург), Самбірській та Більче-Волицькій (тираська світа, баден) зонах (рис. 1). У Бориславсько-Покутській та Самбірській зонах евапорити представлені кам'яною сіллю та калієносними відкладами, у Більче-Волицькій - кам'яною сіллю та гіпсоангідритовими відкладами. У Закарпатському прогині евапоритові відклади знаходяться у Солотвинській та Мукачівській западинах (тереблинська світа, баден) і представлені кам'яною сіллю.

Відклади воротищенської світи поширені лише в Бориславсько-Покутській зоні і залягають смугою вздовж насуву Карпат. У досліджених нами свердловинах на ділянках Борислав (св. 17Др), Верхній Струтин (св. 29), Долина (св. 9МД) потужність відкладів кам'яної солі становить 197, 165, 133 м відповідно. На ділянці Борислав крім кам'яної солі залягають ще і калієносні відклади [18].

Відклади тираської світи у Самбірській зоні вивчалися на ділянці Сілець-Ступниця (св. 348 та 671), потужність відкладів кам'яної солі у цих свердловинах становить 59 і 262 м відповідно. Дискусія про стратиграфічну належність і вік калієносних відкладів Калуш-Голинського родовища та пов'язаних 3 ним ділянок не стосується відкладів кам'яної солі ділянки Сілець-Ступниця - ці відклади усіми дослідниками відносяться до тираської світи $[18,11]$, а їхній баденський вік додатково підтверджений знахідками форамініфер у кам'яній солі цієї ділянки [8]. У Більче-Волицькій зоні відклади кам'яної солі вивчені на ділянці Гринівка (св. 525), біля насуву Самбірської зони, потужність відкладів кам'яної солі 


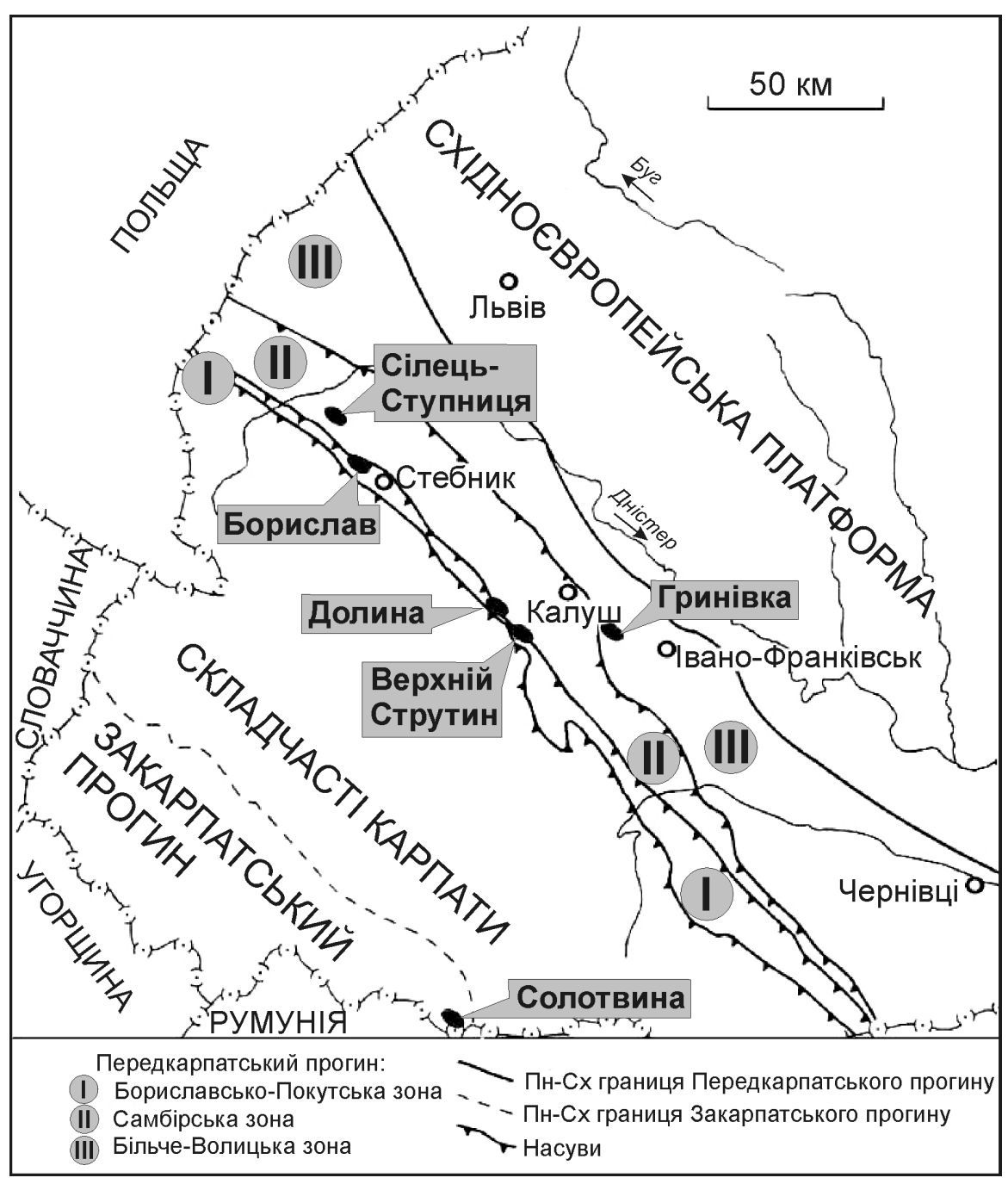

Рис. 1. Розташування досліджених відкладів кам'яної солі у Карпатському регіоні перевищує 258 м (буріння свердловини зупинено в кам'яній солі).

\section{МАТЕРІАЛ I МЕТОД}

Нами рентген-дифрактометричним методом (дифрактометр АДП-2, Со-антикатод, Fе-фільтр) досліджено мінеральний склад 33 проб пелітової фракції водонерозчинного залишку відкладів кам'яної солі воротищенської світи ділянок Верхній Струтин, Борислав, Долина (10 проб), тираської світи ділянок СілецьСтупниця (6 проб) та Гринівка (17 проб) (див. рис. 1). Для Закарпатського прогину використано опубліковані дані.

Дослідження глинистих мінералів проводилося на орієнтованих препаратах із частинками менше 0,001 мм, приготованих методом відмучування. Для визначення мінералів групи монтморилоніту чи утворень, які містять набухаючу компоненту, аналізувалися препарати насичені етиленгліколем і відпалені при температурі $550{ }^{\circ} \mathrm{C}$ протягом 1 години. Структурний тип глинистих мінералів визначався за положенням рефлексів (060) неорієнтованих препаратів.

Для оцінки концентрації розсолів басейну нами використані результати аналізу розчинів індивідуальних рідких включень у галіті, виконаних методом ультрамікрохімічного аналізу [20]. Такі результати для вивчених нами відкладів опубліковані в узагальненому вигляді $[21,16]$, тому ми скористалися люб'язно наданими нам професором В.М. Ковалевичем таблицями з первинними результатами аналізу конкретних зразків, для яких нами вивчався склад глинистих мінералів. Як показник згущення розсолів нами використаний вміст калію, який на початку стадії осадження галіту при згущенні сучасної океанічної води становить 3,9 г/л, а в її кінці - 26,1 г/л [27].

\section{ОТРИМАНІ РЕЗУЛЬТАТИ}

Вивчені відклади кам'яної солі воротищенської та тираської світ відрізняються між собою кількістю та складом глинистих мінералів (табл. 1, рис. 2). Для обидвох цих світ характерними мінералами $€$ гідрослюда та хлорит, які присутні в усіх досліджених пробах. У переважній більшості проб присутня також невелика кількість чи домішка змішаношаруватого утворення гідрослюда-монтморилоніт.

У кам'яній солі воротищенської світи гідрослюда та хлорит знаходяться у значній кількості, змішаношарувате утворення гідрослюда-монтморилоніт у невеликій кількості є в більшості проб (за винятком двох) і власне у цих двох пробах є магнезит; домішка змішаношаруватого утворення хлоритмонтморилоніт відмічена лише двічі.

У кам'яній солі тираської світи вміст гідрослюди та хлориту менший - невелика кількість чи домішка. У переважній більшості проб тираської світи відмічене змішаношарувате утворення хлорит- 

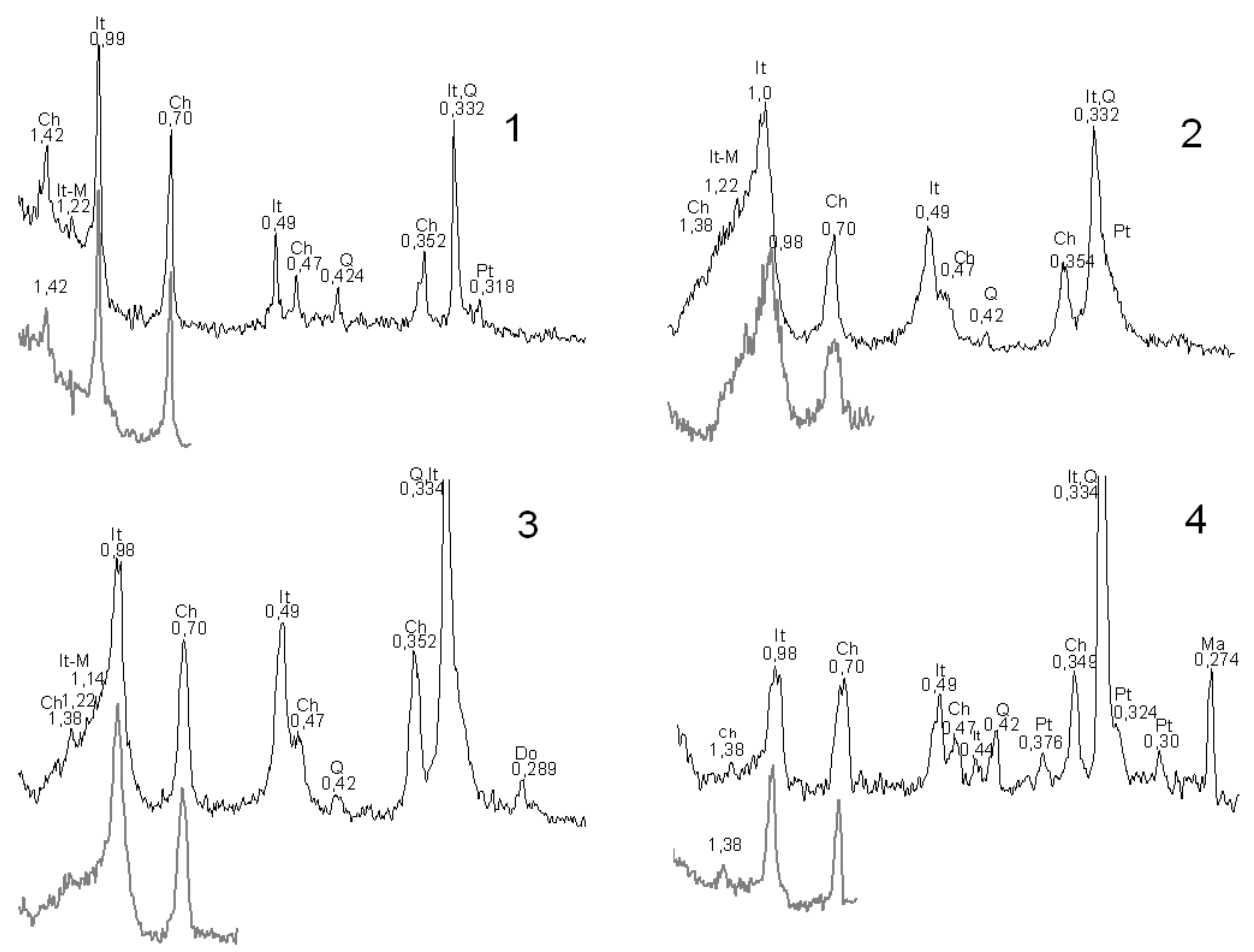

5
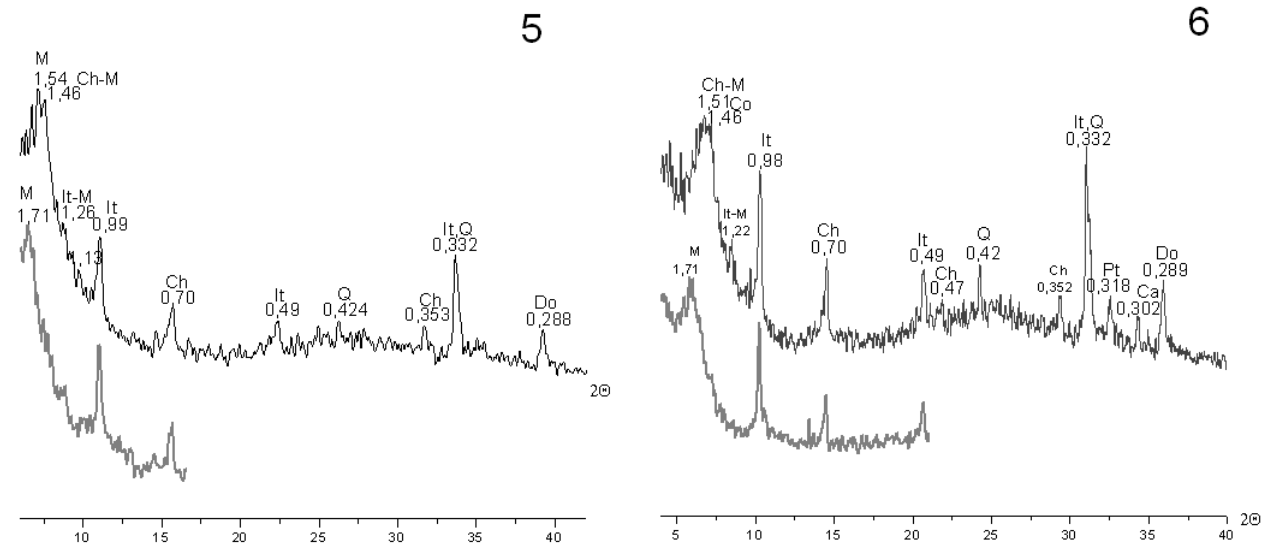

Рис. 2. Дифрактометричні криві водонерозчинного залишку кам'яної солі, фракція менше 0,001 мм. Дифрактограми: верхня - вихідний орієнтований препарат, нижня - насичений етиленгліколем. Воротищенська світа: 1 - зр. 859, св. 9МД, Долина; 2 - зр 2573, св. 29, Верхній Струтин; 3 - зр 2570, св. 17Др, Борислав; 4 - зр 2567, св. 17Др, Борислав; Тираська світа: 5 - зр 47, св. 671, Сілець-Ступниця; 6 - зр 1350, св. 525, Гринівка. Скорочені назви мінералів приведені у примітках до таблиці 1.

монтморилоніт, а гідрослюда-монтморилоніт є лише домішкою. Для кам'яної солі ділянки СілецьСтупниця змішаношарувате утворення хлорит-монтморилоніт в усіх пробах є у значній кількості, коренсит відмічений лише в одній пробі під сумнівом, а монтморилоніт, хоч і є в більшості проб цієї ділянки, але у невеликій кількості. На ділянці Гринівка [24] набухаючі мінерали трапляються часто у значній кількості, тут діагностовані коренсит, монтморилоніт та змішаношарувате утворення хлоритмонтморилоніт, вміст якого у пробі зростає при відсутності або невеликому вмісті коренситу.

Глинисті мінерали досліджених відкладів кам'яної солі представлені диоктаедричною гідрослюдою та триоктаедричним хлоритом, про що свідчить положення рефлексу (060) 0,149 та 0,153 нм відповідно. Гідрослюда характеризується значною асиметрією першого базального рефлексу 1,0 нм зі сторони малих кутів, що може бути спричиненим поганою окристалізованістю, вмістом у структурі міжшарової води чи набухаючих пакетів [22]; хлорит магнезіально-залізистий, на що вказує менша інтенсивність першого та третього базальних рефлексів порівняно з другим [7].

Змішаношарувате утворення гідрослюда-монтморилоніт встановлене за невеликими рефлексами в області 1,22-1,28 нм, які при насиченні препарату етиленгліколем зміщуються до 1,46 нм. Хло- 
Таблиця. Мінеральний склад пелітової фракції водонерозчинного залишку кам'яної солі Передкарпатського прогину

\begin{tabular}{|c|c|c|c|c|c|c|c|c|c|c|c|c|}
\hline \multirow{2}{*}{$\begin{array}{c}\text { № } \\
\text { проби }\end{array}$} & \multirow{2}{*}{$\begin{array}{c}\text { Глибина, } \\
\text { м }\end{array}$} & \multicolumn{6}{|c|}{ Глинисті мінерали } & \multicolumn{5}{|c|}{ Неглинисті мінерали } \\
\hline & & $\mathrm{M}$ & Co & Ch-M & It-M & $\mathrm{Ch}$ & It & $\mathrm{Q}$ & $\mathrm{Pt}$ & Do & $\mathrm{Ca}$ & $\mathrm{Ma}$ \\
\hline \multicolumn{13}{|c|}{ Ділянка В ерхній Струтин, св. 29, воротищенська світа } \\
\hline 2573 & 562 & - & - & - & + & ++ & ++ & $(+)$ & - & - & - & - \\
\hline 2574 & 626 & - & - & - & + & ++ & ++ & $(+)$ & + & - & - & - \\
\hline 2575 & 698 & - & - & - & ++ & ++ & ++ & $(+)$ & + & - & - & - \\
\hline \multicolumn{13}{|c|}{ Ділянка Борислав, св. 17Др, воротищенська світа } \\
\hline 2567 & 352 & - & - & - & - & ++ & ++ & + & + & - & - & ++ \\
\hline 2566 & 353 & - & - & - & - & ++ & ++ & ++ & + & - & - & + \\
\hline 2569 & 377 & - & - & $(+)$ & + & ++ & ++ & + & $(+)$ & $(+)$ & - & - \\
\hline 2570 & 409 & - & - & - & + & ++ & ++ & $(+)$ & - & + & - & - \\
\hline \multicolumn{13}{|c|}{ Ділянка Долина, св. 9МД, воротищенська світа } \\
\hline 858 & 38 & - & - & $+?$ & + & ++ & ++ & - & $(+)$ & $(+)$ & - & - \\
\hline 859 & 73 & - & - & - & + & ++ & ++ & + & $(+)$ & - & - & - \\
\hline 863 & 152 & - & - & - & + & ++ & ++ & $(+)$ & $(+)$ & - & - & - \\
\hline \multicolumn{13}{|c|}{ Ділянка Сілець-Ступниця, св. 348 і 671, тираська світа } \\
\hline 902 & 132 & + & $+?$ & ++ & + & $+?$ & + & $(+)$ & $(+)$ & - & - & - \\
\hline 907 & 172,5 & - & - & ++ & + & + & + & + & - & + & - & - \\
\hline 58 & 272 & + & - & ++ & + & $(+)$ & + & + & - & + & - & - \\
\hline 54 & 302 & - & - & ++ & $(+)$ & + & + & $(+)$ & - & + & - & - \\
\hline 47 & 449 & $+?$ & - & ++ & + & $(+)$ & + & $(+)$ & - & + & - & - \\
\hline 48 & 464 & $+?$ & - & ++ & $(+)$ & $(+)$ & + & - & - & - & - & - \\
\hline \multicolumn{13}{|c|}{ Ділянка Гринівка, св. 525, тираська світа } \\
\hline 1342 & 304 & + & ++ & + & $(+)$ & + & + & + & $(+)$ & - & - & - \\
\hline 1344 & 310,1 & + & + & + & + & + & + & + & $(+)$ & - & - & - \\
\hline 1348 & 330 & $+?$ & - & ++ & $(+)$ & $(+)$ & + & + & - & - & - & - \\
\hline 1350 & 342 & + & $+?$ & ++ & + & $(+)$ & + & $(+)$ & $(+)$ & + & + & - \\
\hline 1352 & 362 & + & $+?$ & ++ & $(+)$ & $(+)$ & + & $(+)$ & - & ++ & - & - \\
\hline 1354 & 376 & - & - & ++ & + & + & ++ & + & $(+)$ & + & + & - \\
\hline 1356 & $395-399$ & + & ++ & $(+)$ & - & $(+)$ & ++ & + & - & + & - & - \\
\hline 1357 & $410-411$ & + & ++ & + & $(+)$ & $(+)$ & + & $(+)$ & + & + & - & - \\
\hline 1361 & $444-448$ & + & ++ & $(+)$ & $(+)$ & $(+)$ & + & $(+)$ & $(+)$ & + & - & - \\
\hline 1362 & $454-456$ & ++ & $+?$ & $(+)$ & + & + & + & $(+)$ & - & + & - & - \\
\hline 1364 & 474 & + & ++ & + & - & $(+)$ & + & $(+)$ & - & + & - & - \\
\hline 1365 & 480 & $+?$ & ++ & + & + & $(+)$ & + & - & - & + & - & - \\
\hline 1366 & 489 & - & $+?$ & ++ & - & + & ++ & $(+)$ & - & + & - & - \\
\hline 1369 & 518 & ++ & ++ & $(+)$ & - & $(+)$ & + & $(+)$ & $(+)$ & + & - & - \\
\hline 1370 & $521-528$ & + & - & ++ & + & $(+)$ & ++ & + & $(+)$ & + & + & - \\
\hline 1371 & 532 & + & $+?$ & ++ & $(+)$ & + & + & + & $(+)$ & - & - & - \\
\hline 1372 & 536 & + & - & ++ & + & + & ++ & + & $(+)$ & - & - & - \\
\hline
\end{tabular}

Примітки: М - монтморилоніт; Со - коренсит; Ch-M - змішаношарувате утворення хлорит-монтморилоніт; It-M - змішаношарувате утворення гідрослюда-монтморилоніт; Ch - хлорит; It - гідрослюда; Q - кварц; Pt - польовий шпат; Do - доломіт; Са - кальцит; Ма - магнезит.

Вміст у пробі: + + значний; + невеликий; (+) домішка; +? наявність під сумнівом; - мінерал не виявлений.

рит-монтморилоніт діагностований за серією рефлексів 1,42-1,55 нм, які при насиченні препарату зміщуються до 1,68-1,71 нм.

Монтморилоніт визначений за поведінкою рефлексу (001), міжплощинна віддаль якого у вихідних препаратах становить 1,51-1,55 нм, у насичених етиленгліколем зміщується до 1,71 нм, а на дифрак- 
тограмах термічно оброблених взірців - до 0,98 нм. Цей дифракційний максимум має розмиту форму та серію малоінтенсивних ліній поганої роздільної здатності, що є ознакою вмісту хлоритових пакетів у структурі монтморилоніту [13]. Визначення монтморилоніту в асоціації із змішаношаруватим утворенням хлорит-монтморилоніт чи коренситом $є$ складним, однак наведені вище докази ми вважаємо достатніми.

Коренсит виявлений за рефлексами 1,42-1,46; 0,78; 0,472; 0,353 нм на дифрактограмах вихідних препаратів, при насиченні етиленгліколем вони набувають значень 1,60; 0,70-0,77; 0,352 нм, а на дифрактограмах відпалених при 550 C препаратів спостерігається рефлекс в області 1,24-1,26 нм. Рефлекс 2,8 нм, який наводиться для коренситу в довідковій літературі, на дифрактограмах досліджених нами зразків має вигляд перегину, або взагалі відсутній, що може свідчити про деяку невпорядкованість у структурі коренситу [13].

Неглинисті мінерали у пелітовій фракції присутні у невеликій кількості чи як домішка, майже в усіх пробах виявлений кварц, часто польовий шпат, рідше доломіт, дуже рідко кальцит чи магнезит.

\section{IНTЕРПРЕТАЦІЯ}

Склад глинистих мінералів та процеси їх перетворення. Генетична інтерпретація визначеної асоціації глинистих мінералів досліджених відкладів кам'яної солі Карпатського регіону основана на уявленнях про хімічну трансформацію глинистих мінералів у солеродному басейні та у сольових осадках на стадіях седиментогенезу та діагенезу. Нестійкі в умовах підвищеної солоності алотигенні мінерали (каолініт, монтморилоніт та змішаношаруваті утворення) під впливом розсолів солеродного басейну через ряд проміжних фаз трансформуються у гідрослюду та хлорит - відбувається захоплення катіонів і впорядкування структури, яке веде до зменшення молекулярного об'єму [23, 4].

Монтморилоніт, який потрапляв у солеродний басейн був або алотигенний, диоктаедричний, що поступав із суші, або новоутворений, триоктаедричний, що виникнув при розкладі вулканічного скла пірокластичного матеріалу [13]. В залежності від того, яким був монтморилоніт - ди- чи триоктаедричним, подальший шлях його трансформації проходив через змішаношаруваті утворення гідрослюда-монтморилоніт та хлорит-монтморилоніт у диоктаедричну гідрослюду та триоктаедричний хлорит.

У міоценовий Передкарпатський солеродний басейн зносилася значна кількість глинистого теригенного матеріалу, про що свідчить високий вміст глини у галогенних відкладах Передкарпаття. При наявності одночасної вулканічної діяльності у солеродний басейн потрапляв також вулканічний попіл, що підтверджується знахідками туфів і туфітів у баденських евапоритах $[17,12]$.

Монтморилоніт, коренсит та змішаношарувата фаза хлорит-монтморилоніт, які виявлені в кам'яній солі тираської світи (ділянки Сілець-Ступниця та Гринівка, Передкарпатський прогин) та тереблинської світи $[15,9]$ (Мукачівська западина, Закарпатський прогин) утворилися при перетворенні вулканічного скла туфів, пов'язаних з баденським вулканізмом. У кам'яній солі тереблинської світи Солотвинської западини (Закарпатський прогин) глинисті мінерали представлені лише гідрослюдою та хлоритом, а змішаношарувате утворення хлорит-монтморилоніт не виявлене [2], що відрізняє ці відклади від інших баденських відкладів Карпатського регіону.

Залежність складу глинистих мінералів від концентрації розсолів евапоритового басейну. Проведені дослідження показали залежність складу глинистих мінералів від концентрації розсолів басейну (навіть у межах галітової стадії згущення). На ділянці Борислав, відклади воротищенської світи якої містять калієносні поклади, у двох верхніх пробах кам'яної солі св. 17Др відсутнє змішаношарувате утворення хлорит-монтморилоніт та з'являється магнезит, а власне магнезит є показником вищої стадії згущення[3].

Також помітна різниця складу глинистих мінералів кам'яної солі ділянок Сілець-Ступниця та Гринівка. Кам'яна сіль ділянки Сілець-Ступниця складена галітом, що відкладався з розсолів з концентрацією калію 7,6-18,8 г/л. У деяких інтервалах концентрація розсолів басейну досягала кінця галітової стадії згущення (20-25 г/л калію), на це вказує також 25-30 см прошарок полігаліту у св. 348 ділянки Сілець-Ступниця [21]. Внаслідок підвищеної концентрації розсолів у кам'яній солі цієї ділянки відсутній коренсит, а монтморилоніт хоч і $є$, але у невеликій кількості.

На ділянці Гринівка концентрація розсолів включень у галіті нижча, вміст калію у розчинах включень у галіті коливається у межах 5,7-8,8 г/л, середнє - 7,0 г/л [24], цим і пояснюється більший вміст у цих відкладах монтморилоніту, коренситу та змішаношаруватого утворення хлорит-монтморилоніт. 
Залежності складу глинистих мінералів від глибини залягання кам'яної солі у досліджених нами зразках не виявлено.

\section{дискусІя}

Монтморилоніт і змішаношаруваті утворення гідрослюда-монтморилоніт та хлорит-монтморилоніт присутні у баденських відкладах кам'яної солі Велички, Польща [26] та Трансільванського басейну, Румунія [25], де вони асоціюють з гідрослюдою, хлоритом, а також каолінітом, який не виявлений у досліджених нами відкладах.

Асоціація глинистих мінералів характерна для баденських відкладів, відрізняється для кам'яної солі Солотвинської западини, бо лише тут кам'яна сіль не містить монтморилоніту, коренситу та змішаношаруватого утворення хлорит-монтморилоніт. Це видається нам дивним, оскільки поява цих мінералів пояснюється надходженням у баденські евапоритові басейни Передкарпатського та Закарпатського прогинів вулканічного матеріалу, а діючі у цей час вулкани розміщувалися на Закарпатті [17], тобто близько від Солотвинської западини. Концентрація калію в розсолах включень у галіті Солотвинської западини коливається в межах 12-25 г/л [15], що при вищих значеннях може бути причиною відсутності набухаючих глинистих мінералів у зразках кам'яної солі досліджених у цитованій роботі [2].

\section{ВИСНОВКИ}

На прикладі дослідження міоценових відкладів кам'яної солі Карпатського регіону України підтверджено, що на галітовій стадії галогенезу у солеродному басейні та у сольових осадках процеси перетворення нестабільних глинистих мінералів протікають не до кінця і асоціація глинистих мінералів містить ще набухаючі мінерали та змішаношаруваті утворення, не характерні для евапоритів вищої стадії згущення.

У відкладах галітової стадії галогенезу міоценових евапоритів Карпатського регіону крім гідрослюди та хлориту виявлені монтморилоніт, коренсит та змішаношаруваті утворення гідрослюда-монтморилоніт і хлорит-монтморилоніт.

У Карпатському регіоні різновікові відклади кам'яної солі егер-еггенбургського (воротищенська світа) та баденського (тираська та тереблинська світи) віку відрізняються між собою кількістю та складом глинистих мінералів. У обидвох світах присутні гідрослюда, хлорит та змішано шарувате утворення гідрослюда-монтморилоніт. Кам'яна сіль тираської та тереблинської світ містить ще монтморилоніт, коренсит та змішаношарувату фазу хлорит-монтморилоніт. Ця асоціація глинистих мінералів пов'язана з баденським вулканізмом - потраплянням у солеродний басейн туфогенного матеріалу та його перетворенням під впливом розсолів.

У межах одновікових відкладів кам'яної солі помітна залежність складу глинистих мінералів від концентрації розсолів евапоритового басейну - при зростанні концентрації зменшується кількість або зникають набухаючі мінерали та змішаношаруваті утворення.

Автори висловлюють вдячність професору В.М. Ковалевичу за наданий для дослідження кам'яний матеріал, первинні таблиці складу розсолів включень у галіті, які були опубліковані в узагальненому вигяді, та критичні зауваження до рукопису статті.

1. Билонижка П.М. Некоторые особенности минерального состава глин нижемоласовых отложений Прикарпатья // Вопросы литологии и петрографии. 1973. - Кн. 2. - С. 113-120.

2. Билонижка П.М. О минеральном составе карбонатов и глин Солотвинского месторождения каменной соли (Закарпатье) // Вопросы геологии и геохимии галогенных отложений: Сб. науч. тр. - Наук. думка, Киев, 1979. - С. 53-61.

3. Билонижка П.М. Магнезит галогенных отложений Предкарпатья, его генетическое и поисковое значение // Эвапориты Украины. - Наук. думка, Киев, 1985. - C. 67-73.
4. Білоніжка П.М. Трансформаційні перетворення теригенних глинистих мінералів під час галогенезу // Мінерал. зб. - 1992. - № 45, вип. 2. - С. 51-56.

5. Білоніжка П.М. Глинисті мінерали - індикатори умов соленагромадження // Геологія і геохімія горючих копалин. - 1992. - Вип. 78, № 1. - С. 95-102.

6. Билонижка П.М., Винар О.Н., Мельников В.С. О минеральном составе глин соляных пород калийных месторождений Прикарпатья // Вопр. минералогии осадочных образований. - Львов, 1966. - Кн. 7. - С. 57-61.

7. Бриндли Г.В. Хлоритовые минералы // Рентгеновские методы изучения и структура глинистых минералов. Мир, Москва, 1965. - С. 284-344. 
8. Венглинский И.В., Копыстянская С.П. Микрофаунистические остатки из соленосных отложений тортона северо-западного Предкарпатья // Вопросы геологии и геохимии галогенных отложений. - Наук. думка, Киев, 1979. - С. 128-135.

9. Габинет П.М., Сливко Е.П. Глинистые минералы из каменной соли района Свалявы в Закарпатье // Минерал. сб. - 1984. - № 38, вып. 1. - С. 56-62.

10. Гринів С.П., Корінь С.С., Білоніжка П.М. Використання глинистих мінералів і карбонатів для вияснення особливостей геологічної будови Стебницького родовища калійних солей // Геологія і геохімія горючих копалин. - 1993. - Вип. 82, № 1 - С. 47-82.

11.Джиноридзе Н.М., Гемп С.Д., Горбов А.Ф., Раевский В.И. Закономерности размещения и критерии поисков калийных солей СССР. - Мецниереба, Тбилиси, 1980. - 373 с.

12. Джиноридзе Н.М., Рогова М.С., Телегин В.П. Вулканогенные породы Калуш-Голынского месторождения калийных солей // Тр. Всесоюз. н.-и. ин-та галургии. 1974. - Вып. 71. - С. 36-56.

13. Дриц В.А., Косовская А.Г. Глинистые минералы: смектиты, смешанослойные образования. - Наука, Москва, 1990. - 214 с.

14. Дриц В.А., Сахаров Б.А. Рентгеноструктурный анализ смешанослойных минералов. - Наука, Москва, 1976. - 256 c.

15. Китык В.И., Бокун А.Н., Панов Г.М., Сливко Е.П., Шайдецкая В.С. Галогенные формации Украины: Закарпатский прогиб. - Наук. думка, Киев, 1983. - 168 с.

16. Ковалевич В.М. Физико-химические условия формирования солей Стебникского калийного месторождения. - Наук. думка, Киев, 1978. - 100 с.

17. Кореневский С.М. Миоценовые вулканические туфы Предкарпатья // Тр. Всесоюз. н.-и. ин-та галургии. 1954. - Вып. 29.

18. Кореневский С.М., Захарова В.М., Шамахов В.А. Ми- оценовые галогенные формации предгорий Карпат. Недра, Ленинград, 1977. - 248 с.

19. Олійович О., Яремчук Я., Гринів С. Глини галогенних відкладів і кори звітрювання Калуш-Голинського родовища калійних солей (міоцен, Передкарпаття) // Мінерал. зб. - 2004. - № 54, вип. 2. - С. 214-223.

20. Петриченко О.Й. Методи дослідження включень у мінералах галогенних порід. - Наук. думка, Киев, 1973. - 92 c.

21. Петриченко О.Й., Ковалевич В.М., Чалый В.Н. Геохимическая обстановка солеобразования в тортонском эвапоритовом бассейне северо-западного Предкарпатья // Геология и геохимия горючих ископаемых. 1974. - Вып. 41. - С. 74-80.

22. Соколова Т.Н. Аутигенное силикатное минералообразование разных стадий осолонения. - Наука, Москва, 1982. - 164 c.

23. Франк-Каменецкий В.А., Котов Н.В., Гойло Э.Л. Трансформационные преобразования слоистых силикатов. - Недра, Ленинград, 1983. - 151 с.

24. Яремчук Я., Галамай А. Геохімічні особливості та мінеральний склад водонерозчинного залишку баденської кам'яної солі ділянки Гринівка Українського Передкарпаття // Геологія і геохімія горючих копалин. 2009. - (в друці).

25. Bican-Bri?an N., Hosu A. Clay mineral association in the salt formation of the Transylvanian basin and its palaeoenvironmental significance // Studia UBB, Geologia. - 2006. - 51 (1-2). - P. 35-41.

26. Cebulak S., Janeczek J., Langer-Ku?niarowa A., Bzowska G. Wska?nikowe znaczenie minera??w ilastych ska? zubrowych w badaniach mioce?skiej formacji solnej // Mioce?skie z?o?a soli w rejonie przykarpackim (Krak?w, 11-12.02.2004). - Krak?w, 2004. - S. 23.

27. McCaffry M.A., Lazar B., Holland H.D. The evaporation path of seawater and the coprecipitation of $\mathrm{Br}$ and $\mathrm{K}$ with halite // J. Sed. Petrol. - 1986. - Vol. 5. - P. 928-937.

Institute of Geology and Geochemistry of Combustible Minerals NAS Ukraine, Lviv, Ukraine

Інститут геології і геохімії горючих копалин НАН України, м. Львів, Україна 